„Śląskie Studia Polonistyczne” 2021, nr 1 (17) ISSN 2353-0928

https://doi.org/10.31261/SSP.2021.17.10

\section{Gherasim Luca}

\section{Pragnienia pragnienia}

Budzik, po który przestrzeń sięga ręką z gipsu należącą do mrocznej, skamieniałej postaci, zamiast wskazówek ma dwie pijane foki. Na cyferblacie pociętym w bloki lodu odwrócone, uroczyste liczby ukazane są jako lustra: godzina lusterka w puderniczce, godzina lustra w garderobie, godzina lustra nad umywalką, godzina gabinetu luster. Wstrząsa mną obraz samotnej krowy na łące w chwili, gdy nożyce, które zjawiły się nie wiadomo skąd, rozkrawają ją na dwie równe części, coś, co przypomina baryton nagle zagłuszony przez sopran. Najbardziej oburza mnie jednak kompletnie arbitralna więź, jaką człowiek - $\mathrm{z}$ iście anielską cnotliwością, z rozwiniętym do perfekcji zmysłem do szybkiego zaspokajania swoich potrzeb - zacieśnia $\mathrm{z}$ dwiema starymi kurwami ludzkiego myślenia: przestrzenią i czasem. To właśnie tym dwóm wampirom udało się wyssać ludzkie mózgi jak cytryny. Głupota, brzydota i strach są w człowieku nieuleczalne i nie wymaga to dodatkowych wyjaśnien. Wystarczy przyjrzeć się byle osobnikowi w kapeluszu, sprawdzającemu raz po raz godzinę na zegarku, żeby zrozumieć, czym jest lenistwo, chciwość czy uległość; albo rzucić okiem na kogoś innego, kto akurat siedzi przy oknie w wagonie kolejowym - cóż za doskonała figura opresji, próżności i religijnych sentymentów. Marzę o tym, aby stać się ucieleśnieniem przestrzeni i czasu tylko po to, by wymierzyć człowiekowi potężny, ba, ostateczny cios w potylicę, podczas gdy w stronę jego głowy wspinałaby się powoli jej własna negacja, niczym trawa z zatrutych luster.

Znałem kiedyś człowieka śniącego o odległych krainach, który oddałby swoje życie, a przynajmniej wywrócił je na nice, za noc w tawernie czy w kaplicy. Inny nie może pogodzić się z przemijaniem, śledzi zmarszczki pojawiające się na czole, jakby były drogami, o które założyło się z nim życie. Jeszcze inny w akcie żałosnej desperacji, w idiotycznej gonitwie za najbanalniejszymi rozwiązaniami, płodzi dziecko albo rezerwuje sobie miejsce na cmentarzu z marmurowym napisem „tu leży”. W każdym geście, w każdym działaniu, w każdym przedsięwzięciu człowieka wyczytuję te same grobowe i cyniczne słowa, zdradzające, że jedyny kontakt z wiecznością ma on poprzez ekskrementy, w transakcji kupna-sprzedaży zaś (na ścianie jednej z restauracji w Bukareszcie można zobaczyć fotografię, metr na sześćdziesiąt cen- 
tymetrów, przedstawiającą niejakiego Gheorghego Niculescu, 1889-1940, fundatora owego przybytku) ten żarłoczny koprofil, smakosz czasu i przestrzeni, ujawnia swój komiczny status we wszechświecie lepiej, niż zrobiłyby to dziesiątki podręczników do filozofii.

Między Niculescu fundatorem restauracji i Schopenhauerem fundatorem systemu filozoficznego rozciąga się przepaść - od śmieszności po straszność. Między tymi biegunami ludzka myśl przeżywa swoją niewinną przygodę, która skrzy się pomysłami niczym kamieniami nagrobnymi, pomysłami zazwyczaj makabrycznymi i rozkosznymi, składającymi się na prawdziwą antologię czarnego humoru: fortepian z ogonem prawdy; wieloryb pełen spalonych pończoch przestrzeni; dwa końskie kopyta o miękkich podkowach (podkowy mogą być zrobione z jogurtu, białek jaj, roztopionego wosku albo z innego materiału o niejednoznacznej konsystencji ni to cieczy, ni to nie-cieczy) tkwiące na ramionach kobiety (przy czym kobieta jest naga, na twarzy ma różową maskę, na nogach różowe pończochy, a na obu kopytach widnieje napis „być”); olbrzymi bęben zostawiony przed wiekami na jakiejś wapnistej łące - dla zasady; sześć eleganckich powozów z zamordowanymi stangretami na kozłach - dla fenomenologii; idea wolności, braterstwa i równości zbudowana z rybich łusek (wolność i braterstwo z karpia, równość ze szczupaka) i ustawiona na marmurowym cokole, który można przesuwać z miejsca na miejsce za pomocą kółeczek - dla rozumu; kilka źdźbeł trawy, serce młodego gołębia, zapach mandragory i czaszka hieny przygotowane zgodnie z magiczną recepturą wprost z jakiegoś podręcznika do magii i rzucone, po obróceniu w proch, wygłodniałemu krukowi - dla pewności; fotografia z wesela pewnej bogatej dziewczyny i młodzieńca z klasy robotniczej, przedstawiająca nowożeńców w otoczeniu rodziny, przyjaciół i znajomych, a także kilku osobistości w typie Engelsa, Freuda, Nietzschego, Beethovena, Kolumba, Maxa Ernsta i Gherasima Luki, wystawiona w witrynie studia fotograficznego - dla pomysłu; dwa jaja w pucharku dla rzeczywistości; popularny wizerunek Szatana dostrzegalny niczym halucynacja na powierzchni talerza z zupą - dla szczegółu i ogółu; nóż znikający w kobiecym dekolcie w tym samym momencie, w którym w sąsiednim salonie parafowany jest traktat pokojowy - dla materii; stary chirurg - dla abstrakcji i konkretu; stół operacyjny przejmujący biologiczne właściwości chorych, a następnie operowany przez tego samego chirurga - dla rzeczy samej w sobie; czarny woal i pierścień należące do księżnej - dla kategorii; blizny na palmie odwzorowywane ręcznie aż do momentu, gdy drzewo się zmęczy pozowaniem - dla istoty; dziura przyniesiona do stołu jako potrawa - dla etyki; pięści zaciśnięte na klamce, która, jak się okazuje, skrywa liczne zielniki, choć okazuje się również, że pięść zaciska się nie na klamce, tylko na 
motylach, a do tego palec w nosie - dla metafizyki; dla samoświadomości - kolekcja znaczków pocztowych, obok których - z taką samą uwagą, jakby to był cień - przechowuje się ślinę do ich lizania; dla pośredniości i bezpośredniości - kapelusz albo i dwa; dla pojedynczości, dla absolutu, dla logiki, dla reprezentacji, dla granicy, dla skutku, dla skończoności, dla trwania - dwie kury kontemplujące aksamit czy błyskawicę, błyskawicę, po której sunie powoli kula, a co może skrywać kula, jeśli nie kulistość, którą ta kula otacza? jeśli nie kwadratowość tkwiącą w podejrzeniach? jeśli nie powieki, nerki, obawę, oddalenie? Obrzydza mnie każde słowo, które piszę, pismo, które redukuje kulę, oczy, rękę, aksamit i oddalenie do losów jakiejś notacji muzycznej albo innego traktatu filozoficznego; odręczne pismo, a w zasadzie sama ręka, ołowiana, całkowicie nierealna, nieistniejąca i fałszywa (albo i prawdziwa, wszystko jedno), dostrzeżona w witrynie antykwariatu, rozpoczyna swoje istnienie (palec w nosie dla istnienia) wyłącznie w chwili, gdy w moim pokoju trafi na figurę średniowiecznego rycerza, którą dotknie palcem w enigmatycznym geście, pomiędzy kilkoma czarnymi kulami przyniesionymi przez kobietę, która zaoferowała mi - w języku, który znają jedynie kobiety i kamienie - swoje okrągłe serce, swoje okrągłe jajniki, swoje okrągłe wargi, swoją okrągłą miłość, a gdy mówię „okrągła”, to rozumie się samo przez się - palec w nosie dla „samo przez się” - że chciałbym również powiedzieć „kwadratowa”, „gorąca”, „kocham cię" i "grudzień”, natomiast gdy mówię "okrągły”, to chciałbym - palec w nosie dla "chciałbym” - nie mówić nic, nie obchodzi mnie - palec w nosie dla „nie obchodzi mnie” - czy coś powiem czy nie, czy coś zakomunikuję, czy wyznam, jedyne, na czym mi zależy, to prowokować, prowokować w samym środku tego pogranicznego świata, w którym poruszam się między życiem a śmiercią, między czasem a przestrzenią, między miłością a nienawiścią, świata pełnego zjawisk, od których się uwalniam tylko po to, by znów mnie doścignęły i okrążyły niczym aureola lśniąca nad metaliczną głową lunatyka; ołowiana ręka, ów materialny, naiwny, dziki symbol miłości, otoczona miłosnymi kulami, u stóp zauroczonego kawalera, między jego nogami, gdzie inna ręka, podobnie amoralna, rozkłada różę krajobrazu - co to za świat, świat jawy i snu wybucha na naszych oczach? Co to za czas, przestrzeń, życie i śmierć powstają, by w mgnieniu oka zastąpić nasze własne życia i śmierci? W tym nieludzkim i antyludzkim świecie, który rodzi się tuż obok mnie, nieomal bez mojej woli (nie zrobiłem nic prócz wypowiedzenia magicznej formuły, naciśnięcia guzika, jestem niczym kula śniegowa, która wywołała całą lawinę konsekwencji), nie może być również mowy o pragnieniach poszukujących zaspokojenia - jak w wypadku czegoś zbyt dobrze znanego, pewnej fazy, którą osiąga się, gdy rzecz dawno przebrzmiała; interesująca jest jedynie sama gonitwa 
pragnień za pragnieniami, skamieniała i chaotyczna; przyjemności są przystankami po drodze - szybkimi, migotliwymi, choć powtarzającymi się bez końca, są tym, czym dla kuli jest jej ciężar; gonitwa zaś jest nieprzerwana, od jednego pragnienia do następnego, każde pragnienie dzięki swej diabolicznej naturze staje się wyzwalaczem kolejnego pragnienia; całując usta, stwarzasz język, język odsyła cię do łechtaczki, łechtaczka sugeruje nóż, którym rozkroisz ofiarę, ofiarę zawsze martwą i żywą niczym jednoczesny przypływ i odpływ miłości.

Przełożył Jakub Kornhauser

Uniwersytet Jagielloński

(iD) https://orcid.org/o000-0002-8904-9788

\section{Przekład na podstawie:}

Gherasim LucA: Dorinţa dorită. In: IDEM: Inventatorul iubirii şi alte scrieri. Ed. Ion Pop. Cluj-Napoca: Editura Dacia, 2003, s. 217-220.

Za udzielenie zgody na opublikowanie tłumaczenia dziękujemy dysponentowi praw autorskich do opowiadania Luki - wydawnictwu Éditions Corti. 